\title{
Dël VLKK koreguotų paprastųjų daiktavardžių kirčiavimo normų
}

\author{
VIDAS KAVALIAUSKAS, GINTARE் PALIUKÉNAITE் \\ Lietuvos edukologijos universitetas, Lietuvių kalbotyros ir komunikacijos katedra, T. Ševčenkos g. 31, LT-03111 Vilnius \\ El.paštas: vidas.kavaliauskas@vpu.lt
}

\begin{abstract}
Valstybinė lietuvių kalbos komisija (VLKK) 2003 m. pakoregavo 45 paprastųjų (pirminių) daiktavardžių kirčiavimo normas. VLKK nutarimas priimtas atsižvelgus i kalbos sistemingumo reikalavimus ir ị kai kuriuos fragmentiškus realios vartosenos duomenis. Išsamesnių realios vartosenos tyrimų atskiruose Lietuvos regionuose ligi šiol nebuvo. Komisija siūlè atskirų paprastųjų daiktavardžiu normas tikslinti nuosekliai laikantis normų keitimo per variantus principo - dažniausiai naujos kirčiavimo gretybès nurodomos kaip antrieji variantai, palyginti retai kai kuriuos nesisteminius kalbos faktus siūlyta keisti radikaliau (jų atsisakyti arba naujuosius variantus iš karto teikti kaip pagrindinius). Kai kuriais atvejais siūlyta atsisakyti buvusių kirčiavimo variantų - palikti tik sistemiškesnius ir dažniau vartojamus. Svarbiausias šio tyrimo tikslas ir uždaviniai - ištirti VLKK Rekomendacijoje (Dèl kai kuriu pirminiu (paprastųju) daiktavardžių kirčiavimo Nr. K-2) koreguotų paprastųjų daiktavardžių kirčiavimo variantų realią vartoseną skirtinguose Lietuvos regionuose. Tyrime dalyvavo 500 žmonių iš skirtingų Lietuvos vietovių, t. y. Lazdijų ir Molètų rajonų, Prienų miesto. Atliktas tyrimas rodo, kad dauguma patikslintų paprastųjų daiktavardžių normų yra remiamos realios vartosenos. Dvylikos paprastųjų daiktavardžių (dumblas, gandras, kardas, rakandas, šalmas, šarvas, tauras, urvas, žvynas, liauka, šlovè, rūšis) naująsias kirčiavimo normas reali vartosena palaiko tik iš dalies. Komisijos įteisinti naujieji antrieji kirčiavimo variantai, anksčiau laikyti kirčiavimo klaidomis, yra gerokai populiaresni už pagrindinius. Pasilikus tokioms vartojimo tendencijoms ir ateityje, kirčiavimo variantai galètų būti sukeisti vietomis. Reali vartosena nepalaiko VLKK sprendimo sukeisti daiktavardžio sébras kirčiavimo variantus vietomis. Šio daiktavardžio kirčiavimo norma ateityje koreguotina. Tyrimo duomenys apie paprastųjų daiktavardžių kirčiavimo realią vartoseną gyvojoje kalboje gali praversti kirčiavimo normų kodifikuotojams, kalbininkams, tyrinëjantiems kirčiavimo normų kaitą, vartosenos polinkius.
\end{abstract}

Raktažodžiai: kodifikuota kirčiavimo norma, reali vartosena, paprastieji (pirminiai) daiktavardžiai, kirtis, bendrinè lietuvių kalba

\section{IVADAS}

Rengiant naująji bendrinès lietuvių kalbos žodyną Valstybinės lietuvių kalbos komisijos (VLKK) Tarties ir kirčiavimo pakomisè 2003-2011 m. atidžiai peržiūrèjo visų kalbos dalių problemiškesnius kirčiavimo atvejus ir, atsižvelgusi ị sistemiškumo reikalavimus ir bendrąsias realios vartosenos tendencijas, pakoregavo nemažos dalies žodžių ir jų formų 
kirčiavimo normas. 2003 m. pakoreguotos 45 paprastųjų (pirminių) daiktavardžių kirčiavimo normos. VLKK nutarimas priimtas atsižvelgus ị kalbos sistemingumo reikalavimus ir ị kai kuriuos fragmentiškus realios vartosenos duomenis. Išsamesnių realios vartosenos tyrimų atskiruose Lietuvos regionuose ligi šiol nebuvo. Komisija siūlè atskirų paprastųjų daiktavardžių normas tikslinti nuosekliai laikantis normų keitimo per variantus principo - dažniausiai naujos kirčiavimo gretybės nurodomos kaip antrieji variantai, palyginti retai kai kuriuos nesisteminius kalbos faktus siūlyta keisti radikaliau (jų atsisakyti arba naujuosius variantus iš karto teikti kaip pagrindinius). Kai kuriais atvejais siūlyta atsisakyti buvusių kirčiavimo variantų - palikti tik sistemiškesnius ir dažniau vartojamus. Svarbiausias šio tyrimo tikslas ir uždaviniai - ištirti VLKK Rekomendacijoje (Dèl kai kurių pirminių (paprastujų) daiktavardžių kirčiavimo Nr. K-2) koreguotų paprastųjų daiktavardžių kirčiavimo variantų realią vartoseną skirtinguose Lietuvos regionuose. Eksperimentinis tyrimas buvo atliktas 2009-2010 m., jame dalyvavo 500 žmonių iš skirtingų Lietuvos vietovių, t. y. Lazdijų ir Molètų rajonų, Prienų miesto. Respondentų buvo prašoma perskaityti sakinius, kuriuose tarp kitų žodžių buvo ir tiriamasis daiktavardis. Tiriamiesiems skaitant sakinius, anketose buvo žymima, kaip jie kirčiuoja rūpimą paprastąji daiktavardị. Tokiu būdu gauti išsamūs rezultatai, atspindintys tirtų daiktavardžių realią vartoseną. Gauti duomenys dar buvo lyginami su Antano Pakerio anksčiau Vilniaus pedagoginiame universitete atliktais kai kurių daiktavardžių kirčiavimo realios vartosenos tyrimais (tyrime dalyvavo studentai). Taigi pagrindinis šio darbo metodas - respondentų apklausa, anketavimas, gautų rezultatų analizé, lyginimas su ankstesniais tyrimų rezultatais, tiriamųjų daiktavardžių kirčiavimo normos fiksavimo kalbinèje literatūroje peržvalga. Atlikti realios vartosenos tyrimai turi ir praktinę vertę - jų rezultatais galès pasinaudoti kirčiavimo normų kodifikuotojai.

Tiriamų daiktavardžių kirčiavimas norminamuosiuose leidiniuose, žodynuose, gramatikose, akcentologijos literatūroje gerokai svyruoja. „Peržvelgus XX a. žodynus, skirtus bendrinės kalbos reikmėms, nesunku pastebėti, jog kai kurių žodžių kirčiavimo normos ivvairuoja. Turbūt nerastume nė poros žodynų (ar šiaip kirčiuotų žodžių sąrašų), kur kirčiavimas visai sutaptų. Žodynų sudarytojai, gramatikų, vadovėlių autoriai nuolat susiduria su žodžiais, neturinčiais stabilių kirčiavimo normų, ir norom nenorom turi rinktis vieną kurị kirčiavimo variantą arba teikti kirčiavimo gretimybių“ $[9,72]$. Kai kurių žodžių norminamuosiuose kalbos leidiniuose fiksuota kirčiavimo norma realios vartosenos seniai nèra palaikoma - tai rodo ir ankstesni kalbininkų pastebejjimai, ir pavieniai realios vartosenos tyrimai (dažniausiai - studentų kalbos). Panaši padètis buvo ir 45-ių paprastųjų daiktavardžių, kurių kirčiavimo normas pakoregavo VLKK. Atsitiktinai pasirinkti Lazdijų ir Molètų rajonų, Prienų miesto gyventojai geranoriškai ir draugiškai dalyvavo 45-ių paprastųjų daiktavardžių kirčiavimo realios vartosenos tyrime. Jie nežinojo, ko siekiama šia apklausa, - tad gautų rezultatų autentiškumu abejoti neverta. Gauti duomenys buvo išanalizuoti ir šiame darbe suskirstyti ị keturias atskiras grupes.

\section{Paprastieji daiktavardžiai, kurių teikiamas patikslintas kirčiavimo normas visiškai} remia reali vartosena. Tokių daiktavardžių užfiksuota dešimt (22,2\%). Jų kirčiavimo norma svyravo įvairiuose lingvistiniuose šaltiniuose. Atlikta apklausa rodo, jog patikslintos šių daiktavardžių kirčiavimo normos yra visiškai remiamos realios vartosenos.

1.1. VLKK pasiūlè 5-ių paprastųjų daiktavardžių palikti tik vieną, pagrindinį, kirčiavimo variantą, o antrojo varianto, neremiamo realios vartosenos, atsisakyti. Toki Komisijos 
sprendimą palaikè ir mūsų tyrime dalyvavę respondentai iš skirtingų trijų Lietuvos vietovių (visose tirtose vietose vyravo variantas, kurị VLKK paliko kaip vienintelị): tiñklas 4 - 458 (91,6 \%) ir tiñklas 2 - 42 (8,4\%); smếlis 2 - 453 (90,6 \%) ir smèlỹs 4 - 47 (9,4 \%); gúoba 1 - $434(86,8 \%)$ ir guobà 4 - $66(13,2 \%)$; skardà 4 - $483(96,6 \%)$ ir skárda 1 - 17 (3,4\%);

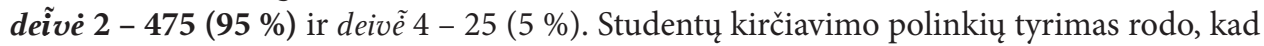
jaunimas irgi palaiko tokị VLKK nutarimą [7, 16, 26, 41].

1.2. Valstybinès lietuvių kalbos komisijos pateiktoje Rekomendacijoje yra pasiūlyta naujųjų antrųjų kirčiavimo variantų, kurie gyvojoje kalboje yra dažni, bet vartojimu nusileidžia pagrindiniam variantui (skilvỹs 4 ir skil̃vis 2; žarnà 3 ir žárna 1) (žr. 1 lentelę).

1 lentelè. Kaip respondentai kirčiavo du paprastuosius daiktavardžius

\begin{tabular}{|c|c|c|c|c|}
\hline & Lazdijų rajonas & Molètų rajonas & Prienai & Iš viso \\
\hline 1.1. skilvỹs (4) & $194(97 \%)$ & $90(60 \%)$ & $97(64,7 \%)$ & $381(76,2 \%)$ \\
\hline 1.2. skiĨvis (2) & $6(3 \%)$ & $60(40 \%)$ & $53(35,3 \%)$ & $119(23,8 \%)$ \\
\hline 2.1. žarnà (3) & $196(98 \%)$ & $85(56,7 \%)$ & $117(78 \%)$ & $398(79,6 \%)$ \\
\hline 2.2. žárna (1) & $4(2 \%)$ & $65(46,3 \%)$ & $33(22 \%)$ & $102(20,4 \%)$ \\
\hline
\end{tabular}

1.3. Kelių paprastųjų daiktavardžių kirčiavimo variantai yra sukeisti vietomis (kìbiras $3^{\text {b }}$ ir kibìras 2; mẽnas 4, 2; audrà 4 ir áudra 1). Daiktavardžio kibiras dabartinè kodifikuota norma buvo teikiama ir senesniuose šaltiniuose: LKŽ 5 725; MŽ 160. Realios vartosenos tyrimas rodo, kad dauguma respondentų palaiko naująji VLKK nutarimą (žr. 2 lentelę ir 1 pav).

\section{2 lentelè. Kaip respondentai kirčiavo daiktavardį kibiras}

\begin{tabular}{|c|c|c|c|c|}
\hline & Lazdijų rajonas & Molètų rajonas & Prienai & Iš viso \\
\hline kìbiras (3 $)$ & $199(99,5 \%)$ & $142(94,7 \%)$ & $134(89,3 \%)$ & $475(95 \%)$ \\
\hline kib̀̀ras $(2)$ & $1(0,5 \%)$ & $8(5,3 \%)$ & $16(10,7 \%)$ & $25(5 \%)$ \\
\hline
\end{tabular}

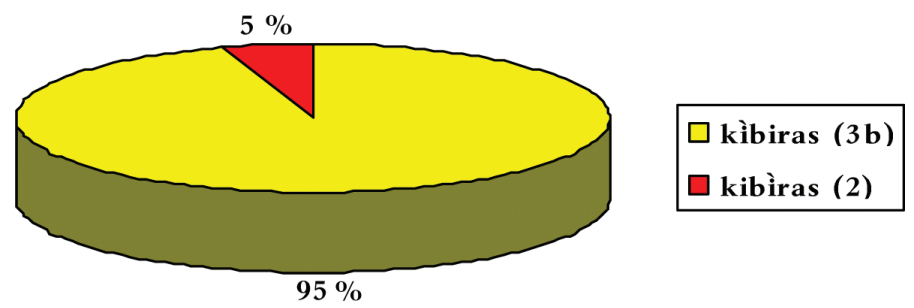

1 pav. Daiktavardžio kibiras kirčiavimo polinkiai

Studentai taip pat akivaizdžiai palaiko $3^{\text {b }}$ kirčiuotès variantą - kìbiras $[7,26]$.

Daiktavardžio menas dabartiniai kodifikuoti kirčiavimo variantai fiksuoti ir anksčiau [MŽ 183; TŽ 170], tik vienas 4 kirčiuotès variantas nurodytas Lietuviu kalbos tarties pagrinduose ir žodyne $[15,588]$. Naujaji pagrindinị kirčiavimo variantą palaiko ir studentai - jų kirčiavimo vartosenos tyrimas rodo, kad nè vienas nesirinko 2 kirčiuotès varianto: mẽnas $4-33$ ir mẽnas $2-0[7,26]$. Naujajj variantą akivaizdžiai labiau palaikè ir mūsų tyrime dalyvavę respondentai iš trijų skirtingų Lietuvos vietų: mẽnas 4 - 496 (99,2 \%) ir 
mẽnas 2 - 4 (0,8 \%). Daiktavardžio audra kirčiavimo norma lingvistinèje literatūroje labai svyruoja: audrà 4 - MLKŽ 29; áudra 1 - 1, 64; 2, 17; 13, 235, 300, 587; 14, 60; 6, 25; 7, 8; LKRŽ 163; audrà 4 ir áudra 1 - 12, 55-56; 3, 41; 8, 5; 15, 250; DŽ 21 ; MŽ 106; LV 190; TŽ 56; áudra 1 ir audrà $4-4,53 ; 17,61 ; 10,8 ; \mathrm{DZ̆}_{1} 52 ; \mathrm{DZ̆}_{3} 62 ; \mathrm{DZ̆}_{4} 62 ; \mathrm{LKŽ} \mathrm{I} 458$. Studentų apklausos duomenys rodo, kad jie palaiko tik 4 kirčiuotès variantą $[7,17]$. VLKK sprendimas sukeisti šio daiktavardžio kirčiavimo variantus vietomis ir teikti kaip pagrindini 4 kirčiuotès variantą yra palaikomas visų respondentų iš skirtingų trijų Lietuvos rajonų: audrà $4-459(91,8$ \%) ir áudra 1 - 41 (8,2 \%).

\section{Paprastieji daiktavardžiai, kurių teikiami abu kirčiavimo variantai yra populiarūs} tarp kalbos vartotojų. Tokių daiktavardžių yra 22 (48,9 \%), jų kirčiavimo variantai nevienodai populiarūs tirtose trijose Lietuvos vietovèse - vienų jų vyrauja pagrindinis kirčiavimo variantas, kitų - antrasis (žr. 3 lentelę).

3 lentelè. Kaip respondentai kirčiavo 22 paprastuosius daiktavardžius

\begin{tabular}{|c|c|c|c|c|}
\hline & Lazdijų rajonas & Molètų rajonas & Prienai & Iš viso \\
\hline 1.1. kréslas (3) & $1(0,5 \%)$ & $80(53,3 \%)$ & $36(24 \%)$ & $117(23,4 \%)$ \\
\hline 1.2. kréslas (1) & $199(99,5 \%)$ & $70(46,7 \%)$ & $114(76 \%)$ & $383(76,6 \%)$ \\
\hline 2.1. pléntas (1) & $197(98,5 \%)$ & $27(18 \%)$ & $16(10,7 \%)$ & 240 (48 \%) \\
\hline 2.2. pleñtas (2) & $3(1,5 \%)$ & $116(77,3 \%)$ & $134(89,3 \%)$ & $253(50,6 \%)$ \\
\hline 2.3. pleñtas (4) & $0(0 \%)$ & $7(4,7 \%)$ & $0(0 \%)$ & $7(1,4 \%)$ \\
\hline 3.1. skrúostas (1) & $197(98,5 \%)$ & $118(78,7 \%)$ & $16(10,7 \%)$ & $331(66,2 \%)$ \\
\hline 3.2. skrúostas (3) & $3(1,5 \%)$ & $32(21,3 \%)$ & $134(89,3 \%)$ & $169(33,8 \%)$ \\
\hline 4.1. smùrtas (1) & $3(1,5 \%)$ & $92(61,3 \%)$ & $32(21,3 \%)$ & $127(25,4 \%)$ \\
\hline 4.2. smur̃tas (2) & $197(98,5 \%)$ & $58(38,7 \%)$ & $118(78,7 \%)$ & $373(74,6 \%)$ \\
\hline 5.1. tùntas (1) & $6(3 \%)$ & $104(69,3 \%)$ & $134(89,3 \%)$ & $244(48,8 \%)$ \\
\hline 5.2. tuñtas (4) & $194(97 \%)$ & $46(30,7 \%)$ & $1(0,7 \%)$ & $241(48,2 \%)$ \\
\hline 5.3. tuñtas (2) & $0(0 \%)$ & $0(0 \%)$ & $15(10 \%)$ & $15(3 \%)$ \\
\hline 6.1. sváinis (1) & $193(96,5 \%)$ & $87(58 \%)$ & $50(33,3 \%)$ & $330(66 \%)$ \\
\hline 6.2. svaĩnis (2) & $7(3,5 \%)$ & $63(42 \%)$ & $100(66,7 \%)$ & $170(34 \%)$ \\
\hline 7.1. lèlỹs (4) & $193(96,5 \%)$ & $70(46,7 \%)$ & $18(12 \%)$ & $281(56,2 \%)$ \\
\hline 7.2. lèlỹs (3) & $7(3,5 \%)$ & $80(53,3 \%)$ & $132(88 \%)$ & $219(43,6 \%)$ \\
\hline 8.1. snarglỹs (3) & $2(1 \%)$ & $25(16,7 \%)$ & $114(76 \%)$ & $141(28,2 \%)$ \\
\hline 8.2. snarglỹs (4) & $198(99 \%)$ & $125(83,3 \%)$ & $36(24 \%)$ & $359(71,8 \%)$ \\
\hline 9.1. žaltỹs (3) & $5(2,5 \%)$ & $34(22,7 \%)$ & $116(77,3 \%)$ & 155 (31\%) \\
\hline 9.2. žaltỹs (4) & $195(97,5 \%)$ & $116(77,3 \%)$ & $34(22,7 \%)$ & $345(69 \%)$ \\
\hline 10.1. balà (2) & $4(2 \%)$ & $104(69,3 \%)$ & $31(20,7 \%)$ & $139(27,8 \%)$ \\
\hline 10.2. balà (4) & $196(98 \%)$ & $46(30,7 \%)$ & $119(79,3 \%)$ & $361(72,2 \%)$ \\
\hline 11.1. dūidà (2) & $4(2 \%)$ & $109(62,7 \%)$ & $132(88 \%)$ & $245(49 \%)$ \\
\hline 11.2. dūdà (4) & $196(98 \%)$ & $41(27,3 \%)$ & $18(12 \%)$ & $255(51 \%)$ \\
\hline 12.1. ýda (1) & $6(3 \%)$ & $134(89,3 \%)$ & $48(32 \%)$ & $188(37,6 \%)$ \\
\hline 12.2. ydà (4) & $194(97 \%)$ & $16(10,7 \%)$ & $102(68 \%)$ & $312(62,4 \%)$ \\
\hline 13.1. léšos (1) & $6(3 \%)$ & $98(65,3 \%)$ & $62(41,3 \%)$ & $166(33,2 \%)$ \\
\hline 13.2. 1ẽšos (4) & $194(97 \%)$ & $52(34,7 \%)$ & $88(58,7 \%)$ & $334(66,8 \%)$ \\
\hline 14.1. porà (3) & $14(7 \%)$ & $86(57,3 \%)$ & $116(77,3 \%)$ & $216(43,2 \%)$ \\
\hline 14.2. porà (4) & $186(93 \%)$ & $64(42,7 \%)$ & $34(22,7 \%)$ & $284(56,8 \%)$ \\
\hline
\end{tabular}


3 lentelè. Tęsinys

\begin{tabular}{|l|c|c|c|c|}
\hline & Lazdiju rajonas & Molètų rajonas & Prienai & Iš viso \\
\hline 15.1. próga (1) & $181(90,5 \%)$ & $65(43,3 \%)$ & $65(43,3 \%)$ & $311(62,2 \%)$ \\
\hline 15.2. progà (4) & $19(9,5 \%)$ & $85(56,7 \%)$ & $85(56,7 \%)$ & $189(37,8 \%)$ \\
\hline 16.1. rinkà (2) & $11(5,5 \%)$ & $68(45,3 \%)$ & $101(67,3 \%)$ & $180(36 \%)$ \\
\hline 16.2. rìnka (1) & $189(94,5 \%)$ & $82(54,7 \%)$ & $49(32,7 \%)$ & $320(64 \%)$ \\
\hline 17.1. skujà (4) & $193(96,5 \%)$ & $62(41,3 \%)$ & $16(10,7 \%)$ & $271(54,2 \%)$ \\
\hline 17.2. skujà (2) & $7(3,5 \%)$ & $88(58,7 \%)$ & $134(89,3 \%)$ & $229(45,8 \%)$ \\
\hline 18.1. vapsvà (4) & $194(97 \%)$ & $72(48 \%)$ & $119(79,3 \%)$ & $385(77 \%)$ \\
\hline 18.2. vapsvà (2) & $6(3 \%)$ & $78(52 \%)$ & $31(20,7 \%)$ & $115(23 \%)$ \\
\hline 19.1. kriauklẽ (4) & $9(4,5 \%)$ & $85(56,7 \%)$ & $16(10,7 \%)$ & $110(22 \%)$ \\
\hline 19.2. kriáuklè (1) & $191(95,5 \%)$ & $65(43,3 \%)$ & $134(89,3 \%)$ & $390(78 \%)$ \\
\hline 20.1. sváinè (1) & $165(82,5 \%)$ & $103(68,7 \%)$ & $100(66,7 \%)$ & $368(73,6 \%)$ \\
\hline 20.2. svaĩnè (2) & $35(17,5 \%)$ & $47(31,3 \%)$ & $50(33,3 \%)$ & $132(26,4 \%)$ \\
\hline 21.1. šerdìs (4) & $196(98 \%)$ & $63(42 \%)$ & $18(12 \%)$ & $277(55,4 \%)$ \\
\hline 21.2. šerdìs (3) & $4(2 \%)$ & $87(58 \%)$ & $132(88 \%)$ & $223(44,6 \%)$ \\
\hline 22.1. úolektis (1) & $194(97 \%)$ & $108(72 \%)$ & $35(23,3 \%)$ & $337(67,4 \%)$ \\
\hline 22.2. uolektìs (3a) & $6(3 \%)$ & $18(12 \%)$ & $115(76,7 \%)$ & $139(27,8 \%)$ \\
\hline 22.3. uolẽktis (2) & $0(0 \%)$ & $24(16 \%)$ & $0(0 \%)$ & $24(4,8 \%)$ \\
\hline
\end{tabular}

VLKK sprendimas teikti abu kirčiavimo variantus (kréslas 3 ir kréslas 1; pléntas 1 ir pleñtas 2; skrúostas 1 ir skrúostas 3; smùrtas 1 ir smur̃tas 2; tùntas 1 ir tuñtas 4; sváinis 1 ir svaĩnis 2; lèlỹs 4 ir lèlỹs 3; snarglỹs 3 ir snarglỹs 4; žaltỹs 3 ir žaltỹs 4; balà 2 ir balà 4; dūdà 2 ir dūdà 4; ýda 1 ir ydà 4; léšos 1 ir lễsos 4; porà 3 ir porà 4; próga 1 ir progà 4; rinkà 2 ir rìnka 1; skujà 4 ir skujà 2; vapsvà 4 ir vapsvà 2; kriauklẽ 4 ir kriáukle 1 ; sváine 1 ir svaĩne 2 ; šerdìs 4 ir šerdìs 3 ; úolektis 1 ir uolektìs $3^{\mathrm{a}}$ ) yra pamatuotas.

\section{Paprastieji daiktavardžiai, kurių pakoreguotas kirčiavimo normas iš dalies palaiko} reali vartosena. VLKK, siūlydama koreguoti kirčiavimo normas, dažniausiai nuosekliai laikèsi naujų variantų teikimo principo: greta anksčiau teikto vienintelio kirčiavimo varianto įteisinti populiaresni variantai. Tokių paprastųjų daiktavardžių yra 12 (26,7 \%): dum̃blas 2 ir dum̃alas 4; gañdras 2 ir gañdras 4; kárdas 3 ir kar̃das 4; rakañdas 2 ir rakándas 1; šálmas 3 ir šal̃mas 4; šárvas 3 ir šar̃vas 4; taũras 4 ir taũras 2; ùrvas 3 ir ur̃vas 4; žvýnas 3 ir žvỹnas 4; liaukà 2 ir liáuka 1; šlovẽ 3 ir šlovẽ 4; rúšis 1 ir rūšìs 4. Toks žingsnis labai svarbus - neiteisinti tokie kirčiavimo variantai anksčiau buvo laikomi kirčiavimo klaidomis. Dabar juos galima vartoti, bet jie kol kas laikomi antraisiais kirčiavimo variantais. Vis dèlto kalbos vartotojai linkę būtent juos dažniau vartoti - tai rodo atliktas jų realios vartosenos tyrimas, studentų kirčiavimo polinkiai. Pavyzdžiui, literatūroje beveik visada buvo nurodomas tik 2 kirčiuotès daiktavardžio gañdras kirčiavimas $[1,62 ; 12,57 ; 7,19 ; 15,342 ; \mathrm{DZZ} 1$ 196; DŽ 2 162; $\mathrm{DŽ}_{3}$ 164; DŽ $\check{1}_{4}$ 164; DŽ ${ }_{6 \mathrm{e}}$; LKŽ 3 98]; 4 kirčiuotès variantas gañdras buvo teikiamas LV. Kai kuriuose senesniuose šaltiniuose [11,54; MŽ 134; TŽ 102] bei naujausiuose leidiniuose [5, 2008, 38], išleistuose jau po Komisijos priimtų korekcijų, galima rasti ir kirčiavimo variantų: gañdras 2, 4. Mūsų atliktas tyrimas rodo, kad ịteisintas antrasis 4 kirčiuotès variantas yra palaikomas realios vartosenos ir akivaizdžiai pirmauja prieš pagrindinị 2 kirčiuotès variantą (žr. 4 lentelę ir 2 pav.). 
4 lentelè. Kaip respondentai kirčiavo daiktavardi gandras

\begin{tabular}{|c|c|c|c|c|}
\hline & Lazdijų rajonas & Molètų rajonas & Prienai & Iš viso \\
\hline gañdras (2) & $3(1,5 \%)$ & $8(16 \%)$ & $0(0 \%)$ & $11(2,2 \%)$ \\
\hline gañdras (4) & $197(98,5 \%)$ & $142(84 \%)$ & $150(100 \%)$ & $489(97,8 \%)$ \\
\hline
\end{tabular}

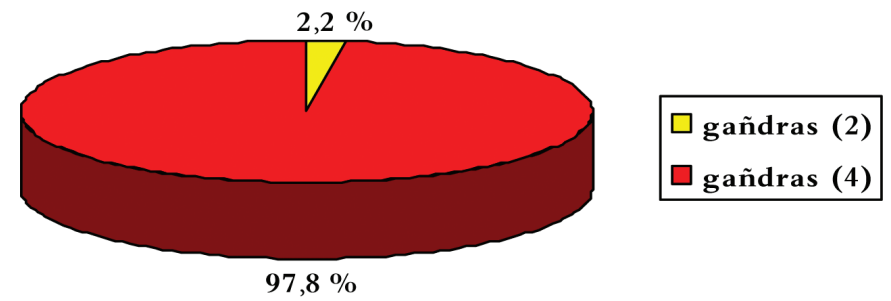

2 pav. Daiktavardžio gandras kirčiavimo polinkiai

Antrąji variantą akivaizdžiai palaiko ir jaunimas: gañdras 2 - 0; gañdras 4 - $54[7,26]$.

Beveik visoje lietuvių lingvistinejje literatūroje daiktavardžio liauka buvo nurodomas tik tvirtagalès šaknies 2 kirčiuotès variantas $\left[15,565 ; 16,28 ; \mathrm{DZ} \check{L}_{1} 420 ; \mathrm{DZ} \check{Z}_{2} 366 ; \mathrm{DZ} \check{Z}_{3} 363 ; \mathrm{DZ}_{4}\right.$ 363; DŽ ${ }_{6 e}$; LV 355; MŽ 175; TŽ 160; ir kt.]. Atliktas šio daiktavardžio realios vartosenos tyrimas rodo, kad VLKK sprendimas ịteisinti antrąjį, tvirtapradès šaknies, variantą (1 kirčiuotè) yra palaikomas realios vartosenos (žr. 5 lentelę ir 3 pav.).

5 Ientelè. Kaip respondentai kirčiavo daiktavardį liauka

\begin{tabular}{|c|c|c|c|c|}
\hline & Lazdijų rajonas & Molètų rajonas & Prienai & Iš viso \\
\hline liaukà (2) & $3(1,5 \%)$ & $11(7,3 \%)$ & $0(0 \%)$ & $14(2,8 \%)$ \\
\hline liáuka (1) & $197(98,5 \%)$ & $139(92,7 \%)$ & $150(100 \%)$ & $486(97,2 \%)$ \\
\hline
\end{tabular}

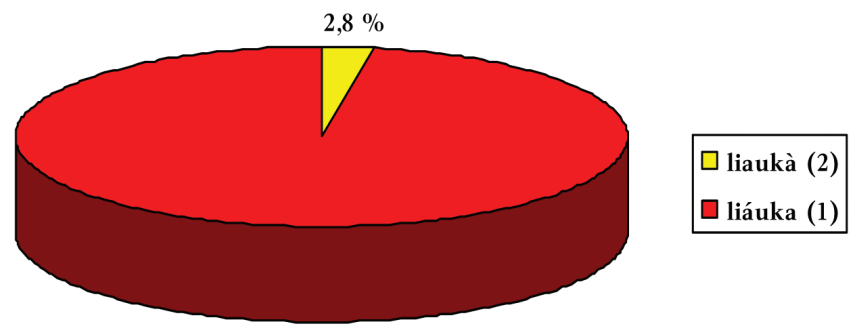

$97,2 \%$

3 pav. Daiktavardžio liauka kirčiavimo polinkiai

Antrąj kirčiavimo variantą akivaizdžiai palaiko ir jaunimas - tai rodo prof. A. Pakerio atliktas VPU studentų lituanistų kirčiavimo polinkių tyrimas: liaukàs - 0, liáukas - 54 $[7,26]$.

Gana nenuosekliai žodynuose ir akcentologijos literatūroje buvo teikiama daiktavardžio žvynas kirčiavimo norma. Pirmajame DŽ buvo teikiamas tik 3 kirčiuotès tvirtapradès šaknies žvýnas; tokia kirčiavimo norma buvo teikiama ir kituose šaltiniuose $[2,148$; 
15, 1240; 16, 31; DŽ 1987 ; LKRŽ 381; MŽ 279]. DŽ 2 radikaliai pakeitė šio daiktavardžio kirčiavimo normą - atsisakyta ankstesnio 3 kirčiuotès varianto ir ịteisinti nauji du variantai: žvỹnas 4 ir žvýnas 1 [žr. DŽ 2 974; TŽ 317]. DŽ 3 padarè naujus radikalius pakeitimus: atsisakyta pagrindinio 4 kirčiuotès varianto ir sugrąžintas 3 kirčiuotès variantas kaip pagrindinis: žvýnas 3 ir žvýnas 1 . Tokia šio daiktavardžio kirčiavimo norma buvo teikiama ir kituose šaltiniuose [7, 30; DŽ 966; DŽ 4966 ; $\check{Z Z}_{6 \mathrm{e}}$ ]. Akademiniame lietuvių kalbos žodyne nurodomi visi keturi galimi variantai: žvýnas 3, 1, žvỹnas 4, 2 [LKŽ 20 1123]. Toks šio daiktavardžio kirčiavimo ịvairavimas rodo, kad būtini išsamūs jo realios vartosenos tyrimai, padèsiantys tinkamai kodifikuoti kirčiavimo normą. VLKK, remdamasi bendromis šio daiktavardžio vartojimo tendencijomis ir normų keitimo per variantus principais, pasiūlè palikti 3 ir 4 kirčiuočių variantus: žvýnas 3, žvỹnas 4 . Atlikti išsamūs tyrimai skirtingose trijose Lietuvos vietose rodo, kad abu kirčiavimo variantai gyvi kalboje (1 ir 2 kirčiuočių variantai jau sunykę), bet vyrauja antrasis 4 kirčiuotès variantas žvỹnas, žvynaî, žvynùs (žr. 6 lentelę ir 4 diagramą).

6 lentelè. Kaip respondentai kirčiavo daiktavardį žvynas

\begin{tabular}{|c|c|c|c|c|}
\hline & Lazdiju rajonas & Molètų rajonas & Prienai & Iš viso \\
\hline žvýnas (3) & $4(2 \%)$ & $18(12 \%)$ & $32(21,3 \%)$ & $54(10,8 \%)$ \\
\hline žvỹnas (4) & $196(98 \%)$ & $132(88 \%)$ & $118(78,7 \%)$ & $446(89,2 \%)$ \\
\hline
\end{tabular}

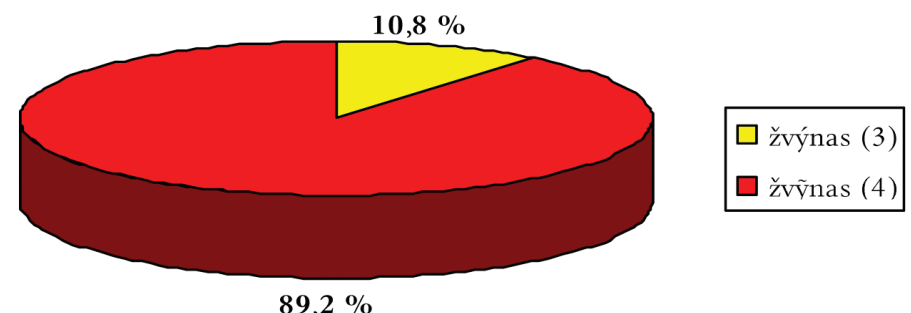

4 pav. Daiktavardžio žvynas kirčiavimo polinkiai

Panašūs rezultatai gauti ir $2011 \mathrm{~m}$. ištyrus Lietuvos edukologijos universiteto studentų lituanistų, neklausiusių akcentologijos paskaitų, daiktavardžio žvynas realią vartoseną - daugumai iš 70 tyrime dalyvavusių studentų labiau priimtinas 4 kirčiuotès variantas: žvỹnas 4 - 53 (75,7 \%) ir žvýnas 3 - 17 (24,3\%).

Ir kitų šios grupès paprastųjų daiktavardžių naujas antrasis kirčiavimo variantas labiau palaikomas realios vartosenos: dum̃alas 2 (42; 8,4 \%) ir duñalas 4 (458; 91,6 \%); kárdas 3 (76; 15,2 \%) ir kar̃das 4 (424; 84,8 \%); rakañdas 2 (1;0,2\%) ir rakándas 1 (499; 99,8\%); šálmas 3 (49; 9,8 \%) ir šal̃mas 4 (451; 90,2 \%); šárvas 3 (70; 14 \%) ir šar̃vas 4 (430; $86 \%$ ); taũras $4(104 ; 20,8 \%)$ ir taũras 2 (396; 79,2 \%); ùrvas $3(46 ; 9,2 \%)$ ir ur̃vas 4 (454; 90,8 \%); šlovẽ 3 (54; 10,8 \%) ir šlovẽ 4 (446; 89,2 \%); rúšis 1 (79; 15,8 \%) ir rūš̀̀s 4 (421; 84,2 \%).

Šių 12-os paprastųjų daiktavardžių ịteisinti antrieji kirčiavimo variantai palaikomi realios vartosenos - tyrime dalyvavę respondentai juos vartoja kaip pagrindinius. Ateityje galima tikètis, kad, išlikus tokiems realios vartosenos polinkiams, teks dar kartą tikslinti šių daiktavardžių kirčiavimo normą ir sukeisti dabar Rekomendacijoje teikiamus variantus vietomis. 
4. Paprastieji daiktavardžiai, kurių pakoreguoto kirčiavimo normų reali vartosena nepalaiko. Toks daiktavardis tèra vos vienas $(2,2 \%) . \mathrm{DZ}_{4}, \mathrm{DZ} \check{ }_{6 \mathrm{e}}$ paprastasis daiktavardis sébras, $-\dot{e}$ kirčiuojamas dvejopai: sébras, $-\dot{e} 1$ ir sẽ ébras, $-\dot{e} 2$. Šio daiktavardžio kirčiavimo norma svyra-

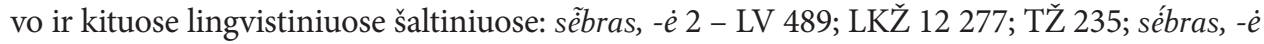

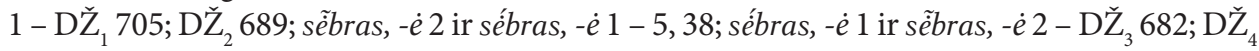
682. VLKK nusprendè sukeisti daiktavardžio sẻbras kirčiavimo variantus vietomis ir pagrindiniu nurodyti 2 kirčiuotès variantą (sếbras, - 2 ir sébras, $-\dot{e} 1$ ). Šio daiktavardžio, slavizmo, tvirtagalès priegaidès variantas nors ir sistemiškesnis (paprastai senieji dviskiemeniai slavizmai bendrinèje kalboje vartojami su tvirtagale šaknies priegaide), bet nèra remiamas realios vartosenos. Atliktas tyrimas rodo, kad absoliuti dauguma respondentų rinkosi anksčiau DŽ teiktą pagrindinį tvirtapradès šaknies variantą (žr. 7 lentelę ir 5 pav.).

7 lentelè. Kaip respondentai kirčiavo daiktavardi sèbras, $-\dot{e}$

\begin{tabular}{|c|c|c|c|c|}
\hline & Lazdijų rajonas & Molètų rajonas & Prienai & Iš viso \\
\hline sẽbras, $-\dot{e}(2)$ & $1(0,5 \%)$ & $0(0 \%)$ & $0(0 \%)$ & $1(0,2 \%)$ \\
\hline sébras, - $\mathrm{e}(1)$ & $199(99,5 \%)$ & $150(100 \%)$ & $150(100 \%)$ & $499(99,8 \%)$ \\
\hline
\end{tabular}

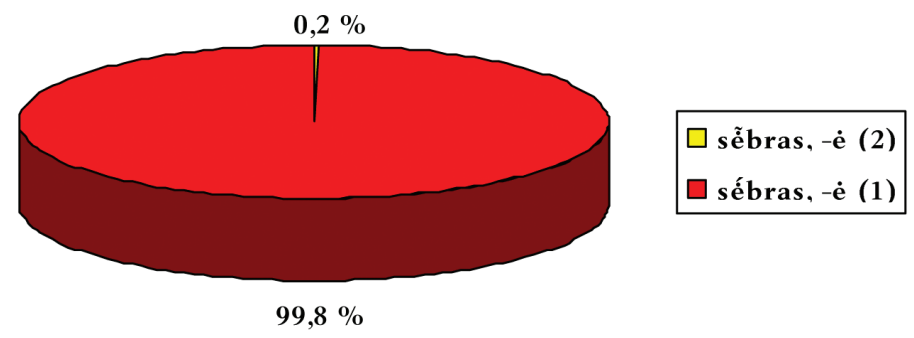

5 pav. Daiktavardžio sèbras, - $\dot{e}$ kirčiavimo polinkiai

Kaip matyti iš gautų duomenų, VLKK nutarimas sukeisti šio daiktavardžio kirčiavimo variantus vietomis nèra palaikomas visuomenès. Išlikus ateityje tokioms kirčiavimo ten-

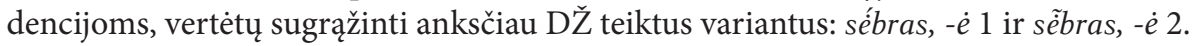

\section{IŠVADOS}

1. Valstybiné lietuvių kalbos komisija 2003 m. pakoregavo 45-ių paprastųjų (pirminių) daiktavardžių kirčiavimo normas. Priimti sprendimai ne tik yra perspektyvūs, bet ir pagrịsti, remiami realios vartosenos. Tai patvirtina trijuose Lietuvos regionuose atliktas paprastųjų daiktavardžių realios vartosenos tyrimas.

2. Valstybinès lietuvių kalbos komisijos pateiktoje Rekomendacijoje yra pasiūlyta naujų antrųjų kirčiavimo variantų (skilvỹs 4 ir skilvis 2; žarnà 3 ir žárna 1), kelių paprastụjų daiktavardžių kirčiavimo variantai yra sukeisti vietomis (kìbiras $3^{\mathrm{b}}$ ir kibìras 2; mẽnas 4, 2; audrà 4 ir áudra 1), kai kurių žodžių antrųjų kirčiavimo variantų atsisakyta (jie kalboje beveik nevartojami), jų kirčiavimo norma kodifikuota be variantų: tiñklas 4; smẽlis 2; gúoba 1; skardà 4; deĩve 2. Atlikta apklausa rodo, kad patikslintos šių daiktavardžių kirčiavimo normos yra visiškai remiamos realios vartosenos.

3. Dvidešimt dviejų paprastųjų daiktavardžių kirčiavimo variantai nevienodai populiarūs tirtose trijose Lietuvos vietovėse - vienų jų vyrauja pagrindinis kirčiavimo variantas, 
kitų - antrasis. Valstybinès lietuvių kalbos komisijos sprendimas teikti abu kirčiavimo variantus (kréslas 3, 1; pléntas 1 ir pleñtas 2; skrúostas 1, 3; smùrtas 1 ir smur̃tas 2; tùntas 1 ir tuñtas 4; sváinis 1 ir svaĩnis 2; lèlỹs 4, 3; snarglỹs 3, 4; žaltỹs 3, 4; balà 2, 4; dūdà 2, 4; ýda 1 ir ydà 4; léšos 1 ir lễsos 4; sváine 1 ir svaĩne 2 ; porà 3, 4; próga 1 ir progà 4; rinkà 2 ir rìnka 1 ; skujà 4, 2; vapsvà 4, 2; kriauklẽ 4 ir kriáukle 1 ; šerdìs 4 , 3; úolektis 1 ir uolektìs $3^{\mathrm{a}}$ ) yra pamatuotas.

4. Dvylikos pirminių daiktavardžių naująsias kirčiavimo normas reali vartosena palaiko tik iš dalies. Komisijos įteisinti nauji antrieji kirčiavimo variantai, anksčiau laikyti kirčiavimo klaidomis, yra gerokai populiaresni už pagrindinius (dum̃blas 2 ir duñablas 4; gañdras 2 ir gañdras 4; kárdas 3 ir kar̃das 4; rakañdas 2 ir rakándas 1; šálmas 3 ir šalmas 4; šárvas 3 ir šar̃vas 4; taũras 4 ir taũras 2; ùrvas 3 ir ur̃vas 4; žvýnas 3 ir žvỹnas 4; liaukà 2 ir liáuka 1; šlovẽ 3 ir šlovẽ 4; rúšsis 1 ir rūš̀s 4). Pasilikus tokioms vartojimo tendencijoms ir ateityje, kirčiavimo variantai galètų būti sukeisti vietomis.

5. VLKK sprendimo sukeisti pirminio daiktavardžio sébras, $-\dot{e}$ kirčiavimo variantus vietomis (sếbras, -e 2 ir sébras, $-\dot{e} 1$ ) nepalaiko reali vartosena. Šio daiktavardžio kirčiavimo norma ateityje galètų būti koreguota.

Gauta 20111117

Priimta 20111213

\section{Literatūra ir šaltiniai}

[1] BÜTĖNAS, Petras. Lietuvių kalbos akcentologijos vadovèlis. Kaunas: Sakalas, 1931. 216 p.

[2] KAMANTAUSKAS, Viktoras. Trumpas lietuviu kalbos kirčio mokslas. II dalis: Kirčio žodynas. Kaunas: „Švyturio“ bendruomenès leidinys, 1929. 156 p.

[3] LAIGONAITĖ, Adelè. Lietuviu kalbos akcentologija. Vilnius: Mokslas, 1978. 123 p.

[4] LAIGONAITE், Adelè. Lietuvių kalbos akcentologija. Vilnius: Gimtasis žodis, 2002. 159 p.

[5] MIKULĖNIENĖ, Danguolè; PAKERYS, Antanas; STUNDŽIA, Bonifacas. Bendrinès lietuviu kalbos kirčiavimo žinynas. Vilnius: Vilniaus pedagoginio universiteto l-kla, 2008. 301 p.

[6] PAKERYS, Antanas. Dvejopas kirčiavimas. Mūsu kalba, 1975, Nr. 6, p. 22-28.

[7] PAKERYS, Antanas. Akcentologija. I dalis. Kaunas: Šviesa, 1994. 423 p.

[8] PAKERYS, Antanas. Kaip kirčiuoti. Gimtoji kalba, 2003, Nr. 8, p. 4-5.

[9] PAKERYS, Antanas. Daiktavardžių kirčiavimo normų kodifikacijos kaita. Aiškinamųjų bendrinés kalbos žodynu aktualijos. Sudarè R. Petrokienè. Vilnius: Lietuvių kalbos institutas, 2006, p. 7489.

[10] PIROČKINAS, Arnoldas. Kirčiavimo spąstai. Gimtoji kalba, 1992, Nr. 10, p. 6-9.

[11] PUPKIS, Aldonas; STUNDŽIA, Bonifacas. Žvilgsnis ị tarties žodyną kodifikacijos ir vartosenos požiūriu. Kalbos kultūra, 1987, Nr. 53, p. 44-57.

[12] SENKUS, Juozas. Aktualūs kirčiavimo klausimai. Kalbos kultūra, 1970, Nr. 19, p. 55-69.

[13] SKARDŽIUS, Pranas. Lietuvių kalbos žodžių daryba. Vilnius: Lietuvių kalbos institutas, 1943. $768 \mathrm{p}$.

[14] SKARDŽIUS, Pranas. Lietuvių kalbos kirčiavimas. Chicago: Pedagoginis lituanistikos institutas, $1968.117 \mathrm{p}$.

[15] VAITKEVIČIŪTĖ, Valerija. Lietuvių kalbos tarties pagrindai ir žodynas. Vilnius: Pradai, 2001. $1241 \mathrm{p}$.

[16] VAITKEVIČIŪTĖ, Valerija. Bendrinès lietuviu kalbos kirčiavimas. Kaunas: Šviesa, 2004. $270 \mathrm{p}$.

[17] VITKAUSKAS, Vytautas. Ar sunkus lietuviu kirčiavimas. Vilnius: Mokslas, 1988. 118 p. 
[18] DŽ - Dabartinés lietuvių kalbos žodynas. Ats. red. J. Kruopas. Vilnius: Valstybinè politinès ir mokslinès literatūros 1-kla, 1954.990 p.

[19] DŽ - Dabartinès lietuvių kalbos žodynas. Ats. red. J. Kruopas. Vilnius: Mintis, 1972. 974 p.

[20] DŽ $\check{z}_{3}$ - Dabartinés lietuvių kalbos žodynas. Vyr. red. St. Keinys. Vilnius: Mokslo ir enciklopedijų 1-kla, $1993.967 \mathrm{p}$.

[21] $\mathrm{DZ̆}_{4}$ - Dabartines lietuviu kalbos žodynas. Vyr. red. St. Keinys. Vilnius: Mokslo ir enciklopediju leidybos institutas, 2000. P. 967.

[22] DŽ ${ }_{6 \mathrm{e}}-$ Dabartines lietuvių kalbos žodynas. Vyr. red. St. Keinys. Vilnius: Lietuvių kalbos institutas, 2006.

[23] LKRŽ - Lietuviu kalbos rašybos žodynas. Ats. red. J. Lazauskas. Kaunas: Valstybinè enciklopedijų, žodynų ir mokslo literatūros 1-kla, 1948. 439 p.

[24] LKŽ 1 - Lietuvių kalbos žodynas. Ats. red. J. Kruopas. T. I. Vilnius: Mintis, 1968. 1230 p.

[25] LKŽ 3 - Lietuviu kalbos žodynas. Ats. red. K. Ulvydas. T. III. Vilnius: Valstybinè politinès ir mokslinès literatūros 1-kla, 1956. 820 p.

[26] LKŽ 5 - Lietuviu kalbos žodynas. Ats. red. K. Ulvydas. T. V. Vilnius: Valstybinè politinès ir mokslinès literatūros l-kla, 1959. 1008 p.

[27] LKŽ 12 - Lietuviu kalbos žodynas. Vyr. red. K. Ulvydas. T. XII. Vilnius: Mokslas, 1981. $1220 \mathrm{p}$.

[28] LKŽ 20 - Lietuvių kalbos žodynas. Vyr. red. V. Vitkauskas. T. XX. Vilnius: Lietuvių kalbos instituto 1-kla, 2002. $1158 \mathrm{p}$.

[29] LV - Lietuviu kalbos vadovas. Sud. P. Skardžius, St. Barzdukas, J. M. Laurinaitis. München: Lietuvių tremtinių bendruomenè, $1950.606 \mathrm{p}$.

[30] MLKŽ - Mokomasis lietuvių kalbos žodynas. Sud. M. Norkaitienè, R. Šepelyté, Z. Šimènaitė. Vilnius: Baltos lankos, 2000. 549 p.

[31] MŽ - Mokomasis lietuviu kalbos rašybos ir kirčiavimo žodynas. Sud. P. Kniūkšta ir A. Lyberis. Kaunas: Šviesa, 1989. 367 p.

[32] TŽ - Lietuvių kalbos tarties žodynas. Sud. V. Vitkauskas. Vilnius: Mokslo ir enciklopedijų leidybos institutas, $2001.318 \mathrm{p}$.

VIDAS KAVALIAUSKAS, GINTARĖ PALIUKĖNAITE்

\section{On the accentuation norms of simple nouns corrected by the State Commission of the Lithuanian Language}

Summary

In 2003, the State Commission of the Lithuanian Language (SCLL) corrected the accentuation norms of 45 simple (primary) nouns. The decision of the SCLL was made with reference to language systemisation requirements and certain fragmentary data of real-life usage. No comprehensive studies of real-life usage in individual regions of Lithuania have been carried out to this day. The Commission proposed to correct the norms of individual simple nouns in consistence with the principle of the change of norms through variants: usually, the new accentuation variants are designated as secondary variants; the proposals to make more radical changes of certain nonsystematic linguistic facts were comparatively rare (to refuse them or to establish 
the new variants as the principal variants at once). In certain cases, the Commission offered to refuse the former accentuation variants by preserving more systematic and more commonly used variants. The key goal and objectives of this study were to find out the actual usage of the accentuation variants of the simple nouns corrected in the SCLL Recommendation (On Accentuation of Certain Simple Nouns, No. K-2) by conducting a survey in various Lithuanian regions. 500 people from different localities of Lithuania (Lazdijai District, Moletai District and Prienai Town) participated in the survey. The survey has revealed that the majority of the corrected norms of simple nouns are supported by real-life usage. In the case of 12 simple nouns (dumblas, gandras, kardas, rakandas, šalmas, šarvas, tauras, urvas, žvynas, liauka, šlové, rūšis), the new accentuation norms are supported by the actual usage only partially. The accentuation variants, previously considered as accentuation mistakes and now established as the secondary accentuation variants by the Commission, are much more popular than the principal variants. With such tendencies of real-life usage in the future, the order of accentuation variants could be reversed. The actual usage does not support the decision of the SCLL to reverse the accentuation norms of the simple noun sébras. The accentuation norm of this noun should be corrected in the future. The research data on the actual accentuation of simple nouns could be of use to the codifiers of accentuation norms and linguists studying the change of accentuation norms and the tendencies of real-life usage.

Key words: codified accentuation norm, real-life usage, simple nouns, stress, Standard Lithuanian 